\title{
Pakistan needs indigenous medicine
}

CHINA's bare-foot doctor, little-educated, trained in his art for only six months, is a constant goad to Pakistan's healthcare officials. Why can't Pakistan have similar people? For the conventional doctor with his Bachelor's degree (a fiveyear, full-time course in medical sciences) is highly expensive and scarce. And even if available, he is not mentally prepared to leave the attractions of the city for the rural areas. So he is ill-equipped to use his medical knowledge.

About three-quarters of Pakistan's people live in the remote countryside, and successive governments have committed themselves to provide a semblance of scientific rural health cover. But there is a largely untapped option in Pakistan, similar to the barefoot doctors of China: the indigenous medicine practitioners. Called the 'hakim', if they practise Greco-Arabic medicine ('Unani Tibb' locally), and 'ved' if they practise 'Ayurvedic', the ancient Indian system, they flourish in the countryside. Could they not be the raw material for a Pakistani bare-foot medical service?

Health care in Pakistan, as in almost the whole of South Asia, is a complex mixture of elements quite different from those in the west. For instance, there are in all about 12,000 conventional doctors in the country for a population of 70 million-hardly one doctor for every 6,000 persons. In practice these provide for only one-fifth of the population. Such a low ratio (for comparison, one doctor to 641 persons in the US, with 45 categories of health personnel to assist him) creates a health care vacuum that fills itself through hakims, veds, homoeopaths and even simple charlatans.

Some 5,000 qualified hakims with diplomas from Unani Tibb colleges already contribute to rural health care; but there are also another 40,000 unqualified hakims who have no formal education nor any medical training. These hakims have learnt just by sitting beside an experienced practitioner in his clinic. Nevertheless, they are recognised and registered practitioners of medicine in Pakistan.

As far as the norms of modern medical science are concerned, even the qualified hakims coming out of the institutions after a 4-year course have a motley education. Along with Greco-Arabic system - which largely works on empirical basis - the hakims are taught several subjects of modern medicine. So the 'kuliyat-e-qanoon' of Avicenna is in the curriculum alongside books on modern physiology, anatomy and so on.

Dr Mazhar H. Shah, a Fellow of the Pakistan Academy of Sciences, writes in his recently-published book the Unity and Integration of Medicine, that "the teaching of modern subjects [to the hakims] is by people not really qualified to teach; and there are no facilities for laboratory diagnosis and hospital treatment. The result is that Tibb colleges produce hakims who wear the stethoscope and prescribe both indigenous as well as imported drugs without any knowledge of basic science or pharmacology. This sort of teaching and practice is neither safe for the seriously ill, nor useful to the national health system".

The cost of modern medicine to provide health care to the entire population of the country, on the other hand, appears simply prohibitive and beyond the reach of a developing country. The medical bill for health services alone in Western countries far outweighs the total of the national budget of Pakistan.

So there is a growing realisation that some sort of integration is imperative between expensive modern medicine and the inexpensive indigenous system, which is largely based on cheap local herbs. Thus the hakim and the ved could be taught the essential principles of the indigenous system but also be adequately equipped with basic principles of modern medical science; and not in half-baked fashion as at present, but in a real professional way. A village doctor emerging from such a scheme could use his discretion to use either the local herb or, if available, the relevant Western drug.

The envisaged integrated system, however, may not find smooth sailing in Pakistan due to the many vested interests. The hakim and the ved is generally opposed to integration, as at present he tries to equate himself in social status with the fully qualified western doctor. So does the homoeopath (homoeopathy is a recognised system of medicine in the country). Strangely enough, a good cross-section of western doctors is also opposed to integration as they think that it would down-grade them if systems based on empirical principles are made to dove-tail with scientific methods.

Political expediency under pressure from the practitioners of indigenous systems led the Government to set up Autonomous Boards for Tibb and Homoeopathy in 1965 so as to let them "train and practise their systems independently by supplementing such modern advances as the Board may, from time to time determine." However, the government also set up (in 1974) an Indigenous Medicines Commission with Dr Salimuzzaman Siddiqui, the chemist, as its chairman to investigate the possibility of integration of the three systems. The eminmission's report was never made public, but it is well-known that it had recommended integration to produce a health service structure on the lines detailed above. But a seal maybe put on the issue by the next civilian government-out of political expediency and to gain political advantage from the strong lobby of tens of thousands 'hakims'. But then that might be the end of integration and also of a practical, down-to-earth answer to rural health care in Pakistan. 